This is the final peer-reviewed accepted manuscript of

FUNARI, VALERIO; Mäkinen, J.; Salminen, J.; BRAGA, ROBERTO; DINELLI, ENRICO; Revitzer, H.: Metal removal from Municipal Solid Waste Incineration fly ash: A comparison between chemical leaching and bioleaching. WASTE MANAGEMENT, 60. ISSN: 0956-053X

DOI: 10.1016/j.wasman.2016.07.025

The final published version is available online at:

http://dx.doi.org/10.1016/i.wasman.2016.07.025

Rights / License:

The terms and conditions for the reuse of this version of the manuscript are specified in the publishing policy. For all terms of use and more information see the publisher's website.

This item was downloaded from IRIS Università di Bologna (https://cris.unibo.it/)

When citing, please refer to the published version. 


\title{
Metal removal from Municipal Solid Waste Incineration fly ash: A comparison between chemical leaching and bioleaching
}

\author{
V. Funari a , J. Mäkinen ${ }^{\text {b }}$, J. Salminen ${ }^{\mathrm{b}, 1}$, R. Braga ${ }^{\mathrm{a}, *}$, E. Dinelli ${ }^{\text {a }}$, H. Revitzer ${ }^{\mathrm{c}}$ \\ a Department of Biological Geological and Environmental Sciences, University of Bologna, Bologna, Italy \\ ${ }^{\mathrm{b}}$ VTT Technical Research Centre of Finland Ltd, Espoo, Finland \\ ${ }^{\text {c } A a l t o ~ U n i v e r s i t y, ~ S c h o o l ~ o f ~ C h e m i c a l ~ T e c h n o l o g y, ~ E s p o o, ~ F i n l a n d ~}$
}

\section{A R T I C L E I N F O}

Keywords:

Municipal Solid Waste Incinerator fly ash

Sulphuric acid leaching

Bioleaching

S- and Fe-oxidizing bacteria

Metal removal

Critical elements

\begin{abstract}
A B S T R A C T
Bio and hydrometallurgical experimental setups at 21 reactor scale for the processing of fly ash from municipal waste incinerators were explored. We aimed to compare chemical $\mathrm{H}_{2} \mathrm{SO}_{4}$ leaching and bioleaching; the latter involved the use of $\mathrm{H}_{2} \mathrm{SO}_{4}$ and a mixed culture of acidophilic bacteria. The leaching yields of several elements, including some of those considered as critical ( $\mathrm{Mg}, \mathrm{Co}, \mathrm{Ce}, \mathrm{Cr}, \mathrm{Ga}, \mathrm{Nb}, \mathrm{Nd}, \mathrm{Sb}$ and $\mathrm{Sm}$ ), are provided. At the end of the experiments, both leaching methods resulted in comparable yields for $\mathrm{Mg}$ and $\mathrm{Zn}(>90 \%), \mathrm{Al}$ and $\mathrm{Mn}$ (>85\%), $\mathrm{Cr}(\sim 65 \%), \mathrm{Ga}(\sim 60 \%)$, and $\mathrm{Ce}(\sim 50 \%)$. Chemical leaching showed the best yields for $\mathrm{Cu}(95 \%), \mathrm{Fe}(91 \%)$, and $\mathrm{Ni}(93 \%)$, whereas bioleaching was effective for Nd (76\%), $\mathrm{Pb}$ (59\%), and $\mathrm{Co}$ (55\%). The two leaching methods generated solids of different quality with respect to the original material as we removed and significantly reduced the metals amounts, and enriched solu tions where metals can be recovered for example as mixed salts for further treatment. Compared to chemical leaching the bioleaching halved the use of $\mathrm{H}_{2} \mathrm{SO}_{4}$, i.e., a part of agent costs, as a likely conse quence of bio produced acid and improved metal solubility.
\end{abstract}

\section{Introduction}

Municipal Solid Waste Incineration (MSWI) systems can reduce waste volume up to $90 \%$ (of the input mass) and simultaneously produce energy for public use (Sabbas et al., 2003). However, the management and recycling of solid by products deriving from MSWI, namely bottom ashes and fly ashes, are of general concern. While the bottom ash is rarely classified as hazardous waste and is typically reused as an aggregate in construction materials (Müller and Rübner, 2006), fly ashes pose the most severe environmental problems. The fly ashes are dust like particles carried away from the combustion chamber with the flue gas that undergo several steps of filtration (e.g., dry/wet scrubber, electrostatic precipitator, chemical bag filter) through the Air Pollution Control (APC) system, before being released into the atmosphere. Despite the mass of pollutants is lower in filtered fly ashes than in raw fly ashes due to the dilution with unreacted additives (e.g., lime and/or soda addition in bag filters) and their neutralization capacity, both materials

\footnotetext{
* Corresponding author at: Department of Biological Geological and Environmental Sciences, University of Bologna, Piazza di Porta San Donato 1, I-40126 Bologna, Italy.

E-mail address: r.braga@unibo.it (R. Braga).

${ }^{1}$ Current affiliation: Boliden Kokkola Oy, Kokkola, Finland.
}

contain large quantities of soluble salts (e.g., $\mathrm{Cl}, \mathrm{Na}$ ) and hazardous metals (e.g., As, $\mathrm{Cd}, \mathrm{Pb}$ ) that are easily volatilised after burning (Funari et al., 2015, 2016b; Astrup et al., 2006) and readily accessible to weathering and transport into the environmental sinks. Consequently, the fly ash material is considered as hazardous waste and is landfilled or stored underground after pre treatment.

Every year the thousands of tonnes of MSWI fly ashes produced might contain $10^{3} \mathrm{~kg} \mathrm{Cu}, \mathrm{Sn}$, and $\mathrm{Sb}, 10^{4} \mathrm{~kg} \mathrm{Al}$ and $\mathrm{Zn}$ (Funari et al., 2015), but their landfilling results in a loss of marketable metals such as $\mathrm{Al}, \mathrm{Cu}, \mathrm{Sn}, \mathrm{Zn}$, and critical raw materials (e.g., $\mathrm{Cr}$, Co, Ga, $\mathrm{Mg}$, $\mathrm{Nb}, \mathrm{Sb}$, and lanthanides; according to the European Commission (2014)) (Funari et al., 2015; Morf et al., 2013). There is, therefore, interest in turning MSWI fly ashes into a secondary resource. Enhancing metal removal and recovery from these alternative sources requires accurate investigations and new technologies need to be compared and combined in order to meet specific aims of treatment.

Desirable approaches are always those capable of both metal recovery and environmental stabilisation (Meawad et al., 2010). Main technologies of MSWI fly ash pre treatment are thermal or hydrometallurgical processes. The hydrometallurgical approach may lead to a safe disposal of precipitates and eluates and to the recovery of valuable metals (by means of subsequent reprecipitation from solutions) with relatively low energy demand and toxins 


\section{Nomenclature}

C concentration of the treated sample (mass/mass)

C0 concentration of the untreated sample (mass/mass)

i index for element

j index for batch

M mass of the batch after treatment (mass)

M0 mass of the batch before treatment (mass)

APC Air Pollution Control

BAFU Federal Office for the Environment, Switzerland

d day

FA BIO fly ash subjected to bioleaching

FA $\mathrm{H}_{2} \mathrm{SO}_{4}$ fly ash subjected to sulphuric acid leaching

FA RAW untreated raw fly ash
FA WW fly ash after water washing

ICP AES Inductively Coupled Plasma Atomic Emission Spectroscopy

L/S liquid solid ratio

LOI loss on ignition

MSWI Municipal Solid Waste Incineration

$\mathrm{R} \%$ removal rate (yield)

RSD Relative Standard Deviation

SD standard deviation

TCPL Toxicity Characteristic Leaching Procedure

XRF $\quad \mathrm{X}$ ray fluorescence spectrometer release. Various studies have investigated wet extraction processes by using chelating agents (Hasegawa et al., 2014; Hong et al., 2010), mineral or organic acids (Meawad et al., 2010 and reference therein) and bio produced acids (Lee and Pandey, 2012 and reference therein, Brombacher et al., 1998). However, the majority of literature works focuses on the leaching behaviour of toxic metals and a handful of other elements (Astrup et al., 2006; Huang et al., 2007), which can primarily endanger the environmental and human health, and outlines the influence of experimental parameters such as time, temperature, reagents used, and liquid solid ratio (Hong et al., 2010; Zhang and Itoh, 2006).

In this work we focus on two leaching methods for subsequent metals recovery from MSWI fly ash, namely chemical leaching and bioleaching, in acid solution. A comparison of their leaching yields is provided in order to asses an affordable pre treatment strategy prior to metal recovery. Leaching behaviour and recovery potential of $\mathrm{Mg}, \mathrm{Co}, \mathrm{Cr}, \mathrm{Ga}, \mathrm{Nb}, \mathrm{Sb}$, La, Ce, Nd, and Sm (hereafter critical elements), $\mathrm{Al}, \mathrm{Cu}, \mathrm{Mn}, \mathrm{Sn}$, and $\mathrm{Zn}$ (hereafter marketable elements), $\mathrm{Ca}$, $\mathrm{Fe}$, and $\mathrm{Ti}$ (unvalued elements), $\mathrm{As}, \mathrm{Ba}, \mathrm{Mo}, \mathrm{Ni}, \mathrm{Pb}, \mathrm{Sr}$ and $\mathrm{V}$ (haz ardous elements) are discussed. Chemical leaching by means of sulphuric acid was used because it is found to be effective in metal removal (Nagib and Inoue, 2000) and relatively less expensive than other strong acids (Meawad et al., 2010). Conversely, in the bioleaching procedure we employed a mixed culture with sulphur and iron oxidizing bacteria that are commonly used at industrial scale for the bioleaching of sulphide ores (Bosecker, 1997; Rawlings, 2002). Recent works demonstrated these bacteria are adaptable to MSWI substrate (Brombacher et al., 1998; Ishigaki et al., 2005) and, thereby, contributed to increase the interest on bio-assisted approach and its capabilities.

The present paper will help to figure out what procedure results in more enriched process solutions, where metals can be recovered by further treatment, and in more stable solids. Emphasis is given on the bioleaching method, which is relatively unexplored for the treatment of MSWI fly ashes and shows major potential for improvements.

\section{Experimental section}

\subsection{Materials}

The studied fly ash comes from an Italian grate furnace incinerator with thermo recycling technology, which burns $90 \%$ house hold waste and $10 \%$ of special waste. The latter input source consists of processing waste from ceramics and metallurgy, automobile shredder residues, hospital and pharmaceutical wastes. The main output products of the MSWI are bottom and fly ashes.

The investigated fly ash material derives from the dry scrubber located after the combustion chamber and prior to the chemical bag filters within the APC system. This fly ash can be defined as untreated raw fly ash (hereafter FA RAW) and represents the most undiluted, hence hazardous, residue deriving from the APC. The output flow of the FA RAW is $3.210^{3} \mathrm{t} / \mathrm{a}$ at the year of the sampling, according to the facility report.

The samples were collected in May 2013 from a big bag (order of hundreds of kilograms) after blending a large number of increments, as in Funari et al. (2015). Colour and grain size of the collected samples were homogeneous upon visual inspection. The FA RAW was recovered into the big bag during normal and stable operation of the combustor. The MSWI system allowed the separate recovery of the FA RAW and other APC residues (e.g., fly ashes from chemical bag filters; for details, the reader can refer to a previous paper (Funari et al., 2016a).

\subsection{Leaching procedure}

\subsubsection{Pre treatment of fly ash material}

The collected primary sample (approximately $10 \mathrm{~kg}$ ) was oven dried at low temperature $\left(40^{\circ} \mathrm{C}\right)$ for one week, grounded, homogenised and very fine milled $(<40 \mu \mathrm{m})$ with an agate vibratory mill disk, before being used in the experiments. The milled material of FA RAW was firstly analysed and then used as starting material before bio hydrometallurgical treatments.

In order to remove water soluble salts, the FA RAW was washed with distilled water prior to the leaching step. The washing treatment promotes leaching efficiency during both chemical leaching (Zhang and Itoh, 2006) and bioleaching methods (Wang et al., 2009). A 10:1 liquid solid ratio (L/S) and three steps of washing were used, since they have been found to be enough to dissolve the most of water soluble salts (Nagib and Inoue, 2000). The solid residue and the liquid were separated using a centrifuge (Allegra X 15R, Beckman Coulter). After separation, the washed residue (hereafter FA WW) was dried at $105^{\circ} \mathrm{C}$ for 24 $\mathrm{h}$ and used through out the experiments. At the beginning of the experiments, the chemical parameters of FA WW were: $11.5 \mathrm{pH}$ and $135 \mathrm{mV}$ red ox potential.

\subsubsection{Chemical leaching}

The FA WW (10\% v/v) and distilled water (90\% v/v) were treated with $\mathrm{H}_{2} \mathrm{SO}_{4}$ in a 21 glass reactor equipped with a top entered agitator and an aeration system, which supplied a continuous airflow from the bottom of the reactor (Fig. 1). Rotation speed of $320 \mathrm{rpm}$ and airflow rate of $1.0 \mathrm{l} / \mathrm{min}$ were used. As high temperatures do not improve remarkably leaching kinetics and yields in sulphuric acid leaching of MSWI fly ashes (Nagib and Inoue, 2000), the reactor operated at room temperature. In order to investigate leaching as a function of $\mathrm{pH}$, several $\mathrm{pH}$ intervals (i.e., $\mathrm{pH}$ 1.0, 3.0, 5.0, 7.0, 9.0 ) have been sampled, after a leaching time of $30 \mathrm{~min}$ in which 


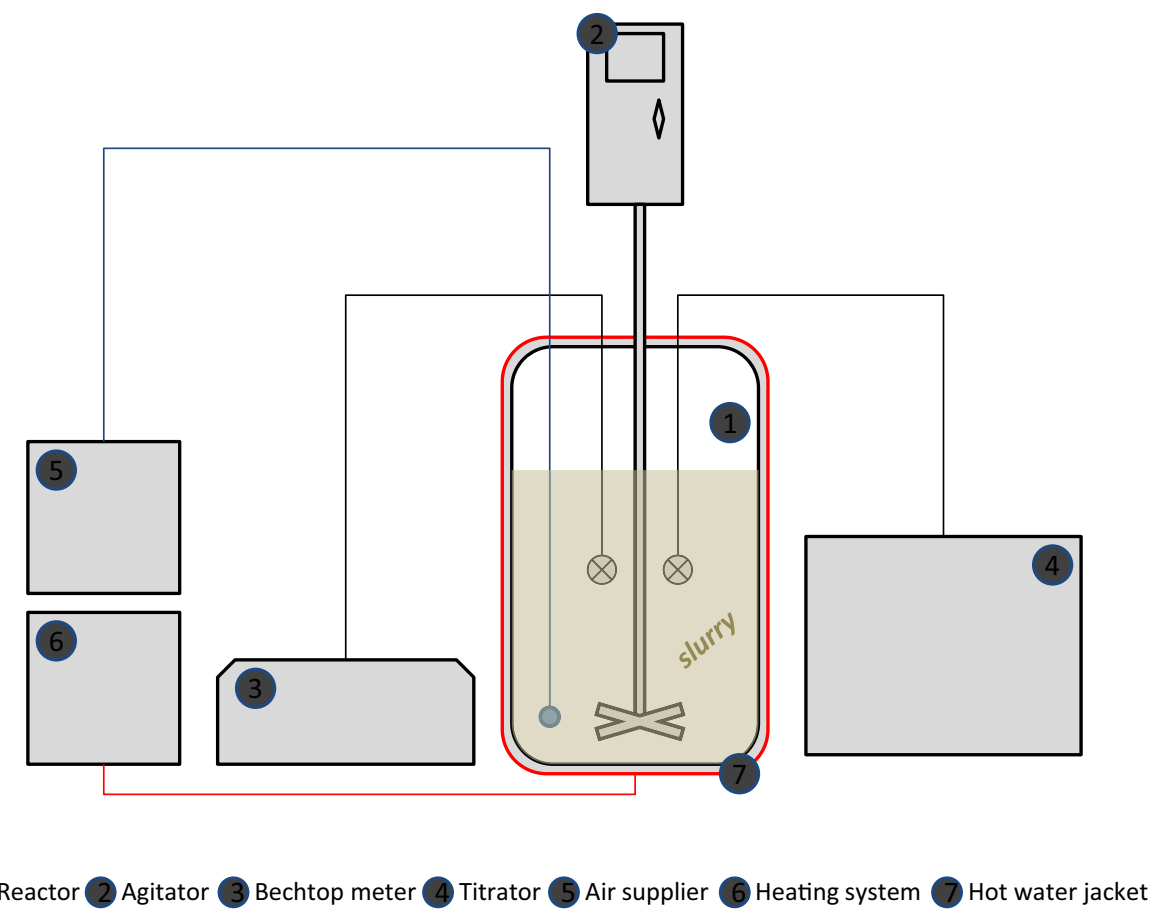

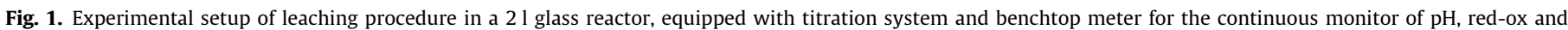
temperature.

the $\mathrm{pH}$ level was maintained constant by $4 \mathrm{M} \mathrm{H}_{2} \mathrm{SO}_{4}$ titration (T70, Mettler Toledo). A reaction time of $30 \mathrm{~min}$ was used because it is generally adequate to achieve good leaching performances (Nagib and Inoue, 2000). The overall duration of the leaching experiment was six hours. A benchtop meter (Consort C3040) was used in order to monitor $\mathrm{pH}$, red ox $(\mathrm{Ag} / \mathrm{AgCl}$ in $3 \mathrm{M} \mathrm{KCl})$ potential and temperature values. The liquid solution was collected using a vacuum filtration system and a $0.45 \mu \mathrm{m}$ glass fibre filter. After vacuum filtration, several elements were determined in the leachate ( $\mathrm{Ca}, \mathrm{Al}$, $\mathrm{Fe}, \mathrm{Cu}, \mathrm{Cr}, \mathrm{Sb}, \mathrm{Sn}, \mathrm{Zn}$ ) using ICP AES, while the solid precip itate was poured again into reactors in order to avoid weight loss and dilution effects during the experiments. Only the final solid precipitate was analysed for total elemental chemistry by XRF, after being washed using two times of its volume of distilled water in order to remove the water soluble materials (mainly salts), oven dried, and exactly weighted for further mass balance assessment.

\subsubsection{Bioleaching: preliminary adaptation of the bacteria mixture and experimental setup}

For bioleaching a mixed acidophilic culture, enriched from a sulphide ore mine site (Halinen et al., 2009), containing At. ferroox idans, At. thiooxidans, At. caldus, L. ferrooxidans, Sb. thermosulfidoox idans, Sb. thermotolerans and some members of Alicyclobacillus genus was used. These bacteria use metal sulphide phases and also elemental sulphur as their substrate to produce sulphuric acid (Bosecker, 1997; Rawlings, 2002; Sand et al., 2001) through the reaction:

$$
\mathrm{S}^{0}+1.5 \mathrm{O}_{2}+\mathrm{H}_{2} \mathrm{O} \rightarrow 2 \mathrm{H}^{+}+\mathrm{SO}_{4}^{2}
$$

Metal sulphides are found as minor phases within MSWI ashes (e.g., Bayuseno and Schmahl, 2011), therefore, when treating this kind of unconventional materials, sulphur oxidizing bacteria must be fed with elemental sulphur to achieve sulphuric acid production and promote leaching. The culture was cultivated in a modified Silverman $9 \mathrm{~K}$ medium (Silverman and Lundgren, 1959), containing $\left(\mathrm{NH}_{4}\right)_{2} \mathrm{SO}_{4} 3.0 \mathrm{~g} / \mathrm{l}, \mathrm{K}_{2} \mathrm{HPO}_{4} 0.5 \mathrm{~g} / \mathrm{l}, \mathrm{MgSO}_{4} 7 \mathrm{H}_{2} \mathrm{O} 0.5 \mathrm{~g} / \mathrm{l}, \mathrm{KCl} 0.1 \mathrm{~g} / \mathrm{l}$,
$\mathrm{Ca}\left(\mathrm{NO}_{3}\right)_{2} 0.01 \mathrm{~g} / \mathrm{l}, \mathrm{FeSO}_{4} 7 \mathrm{H}_{2} \mathrm{O} 22.5 \mathrm{~g} / \mathrm{l}$ and also $10.0 \mathrm{~g} / \mathrm{l} \mathrm{S}^{0}$. The modified $9 \mathrm{~K}$ medium was adjusted to $\mathrm{pH} 2.0$ with concentrated $\mathrm{H}_{2} \mathrm{SO}_{4}$. The culture was incubated in a rotary shaker $(150 \mathrm{rpm})$ and the temperature was set to $30^{\circ} \mathrm{C}$ due to mesophilic At. thioox idans (Rawlings, 2002). The culture was renewed every 15 days by inoculating $10 \%(\mathrm{v} / \mathrm{v})$ of former cultivation and $90 \%(\mathrm{v} / \mathrm{v})$ of the modified $9 \mathrm{~K}$ medium.

The original acidophilic culture was adapted to tolerate the presence of MSWI fly ash and the adaptation experiment was conducted in $250 \mathrm{ml}$ Erlenmeyer flasks containing $90 \mathrm{ml}$ of the modified $9 \mathrm{~K}$ medium. Flasks were inoculated with the acidophilic culture $(10 \% \mathrm{v} / \mathrm{v})$ followed by the addition of the FA WW. The $\mathrm{pH}$ was adjusted to 2.0 with concentrated $\mathrm{H}_{2} \mathrm{SO}_{4}$ and flasks were incubated in a rotary shaker $\left(150 \mathrm{rpm}, 30^{\circ} \mathrm{C}\right)$. If a spontaneous decrease in $\mathrm{pH}$ was observed during 15 days, a new modified $9 \mathrm{~K}$ medium with an increased amount of FA WW was prepared and inoculated with the former solution $(10 \% \mathrm{v} / \mathrm{v})$ of the adaptation experiment. The amounts of solid FA WW were increased three times $(1,2$, and $5 \%$ ) of $\mathrm{L} / \mathrm{S}$ ratio, respectively.

After the adaptation experiment, a scaled up experiment was conducted in a 21 glass reactor with a similar setup as for chemical leaching (Fig. 1) by using the same sample mass of FA WW (100 g) to obtain more representative results. Rotation speed of $320 \mathrm{rpm}$ and airflow rate of $1.0 \mathrm{l} / \mathrm{min}$ were used. The reactor temperature was maintained at $30^{\circ} \mathrm{C}$ using a heated water jacket. The reactor contained $90 \%(\mathrm{v} / \mathrm{v})$ modified $9 \mathrm{~K}$ medium (without $\mathrm{FeSO}_{4} 7 \mathrm{H}_{2} \mathrm{O}$ ) and the previously adapted acidophilic culture $(10 \% \mathrm{v} / \mathrm{v})$. The $\mathrm{pH}$ was fixed to 2.0 with concentrated $\mathrm{H}_{2} \mathrm{SO}_{4}$ and precultivation of microorganisms was conducted for 4 days without FA WW sample. Then, $5 \%(\mathrm{v} / \mathrm{v})$ of FA WW sample was introduced and bioleach ing continued for 21 days with $\mathrm{pH}$ fixing to $\mathrm{pH} 1.8$ (i.e., set point) with concentrated $\mathrm{H}_{2} \mathrm{SO}_{4}$, if necessary.

\subsection{Analytical techniques}

The total elemental chemistry of solid material was determined on pressed powder pellet ( $\varphi 37 \mathrm{~mm}$ ) by a wavelength dispersive 
XRF, PANalytical Axios, equipped with a $4 \mathrm{~kW}$ Rh tube. The SuperQ 3.0 software was used for online correction and analytes quantification. The estimated precision for trace element $(<0.01 \mathrm{wt} . \%)$ determinations is better than $5 \%$ except for those elements at 10 $\mathrm{mg} / \mathrm{kg}$ and lower (10 15\%). Triplicate samples analysis was car ried out in order to assess the precision of measurements by means of standard deviation (SD) and, in addition, a MSWI fly ash reference material (BCR CRM 176) was analysed as unknown sample to evaluate precision and accuracy of the analytical method (see Supplementary materials). Total loss on ignition (LOI) was gravimetrically estimated after overnight heating at $950{ }^{\circ} \mathrm{C}$.

The leachates were analysed by ICP AES (Perkin Elmer). The solutions were completely dissolved with aqua regia in closed alumina bombs at $170{ }^{\circ} \mathrm{C}$ until the digested solution was clear. Element quantification employed calibration curves prepared with diluted standard solutions.

\subsection{Metal removal}

The measured concentrations of solid residues and leached solution obtained by XRF and ICP AES, respectively, are used to evaluate the percentage of metal removal (yield), $\mathrm{R} \%$, which is defined as:

$$
\mathrm{R}_{\mathrm{ij}} \% \quad\left(1 \quad \mathrm{C}_{\mathrm{ij}} \mathrm{M}_{\mathrm{j}} / \mathrm{CO}_{\mathrm{ij}} \mathrm{MO} 0_{\mathrm{j}}\right) \cdot 100
$$

where $\mathrm{R}_{\mathrm{ij}}$ is the degree of removal of the element $i$ in the batch $j, \mathrm{C}_{\mathrm{ij}}$ is the concentration of the element $i$ in the batch $j$ in the treated sample, $\mathrm{M}_{\mathrm{j}}$ is the mass of the treated sample of batch $j, \mathrm{CO}_{\mathrm{ij}}$ is the concentration of the element $i$ in the batch $j$ in the untreated sample and $\mathrm{MO}_{\mathrm{j}}$ is the mass of the untreated sample of batch $j$.

\section{Results and discussion}

\subsection{Characterisation of the untreated raw fly ash}

The Table 1 reports the bulk elemental content of the FA RAW as an average of three samples. The FA RAW is characterised by high amounts of $\mathrm{Ca}, \mathrm{S}, \mathrm{Cl}$, and $\mathrm{Si}$, being their oxides weight fractions of about 20,24,13, and $9 \mathrm{wt} . \%$, respectively. The concentrations of several elements such as $\mathrm{Cr}, \mathrm{Cu}, \mathrm{Pb}, \mathrm{Sb}$, and $\mathrm{Zn}$ are remarkably high: the FA RAW sample contains $>1$ wt.\% of $\mathrm{Zn}$, and about one order of magnitude less of $\mathrm{Cr}, \mathrm{Cu}, \mathrm{Pb}$, and $\mathrm{Sb}$. Despite a limited amount of primary sample (about $10 \mathrm{~kg}$ ) was collected due to logistical reasons, the SD values for most of the major elements are within a narrow range, suggesting a relative homogeneity of the sampled material. The representativeness of fly ash material can be further assessed by comparing the analysis of FA RAW sample with concentrations range quoted in literature and recently outlined in Funari et al. (2015). The quality check of the XRF measurements showed good results for the most of critical elements in term of relative error (see Supplementary materials). Some discrepancies occurred for $\mathrm{Al}, \mathrm{Co}, \mathrm{K}, \mathrm{Mn}$, and $\mathrm{Cl}$, and this might lead to an under estimation of their leaching yields and recovery potential, according to the relative error.

\subsection{Effect of pre washing}

High contents of $\mathrm{Cl}$ and mineral salts like those of $\mathrm{Na}$, Ca, K typ ically hamper an efficient recovery of metals from MSWI fly ashes (Okada et al., 2007). Alkali salts consume large amounts of acid during the leaching and they may also complicate the separation of valuable metals bonded with them. The fly ash pre washing removed most of water soluble salts (Fig. 2). More than $80 \%$ of $\mathrm{Cl}, \mathrm{K}$ and $\mathrm{Na}$ were removed, in agreement with previous works (Nagib and Inoue, 2000; Wang et al., 2009).
Table 1

Chemical composition of the untreated raw fly ash, FA-RAW, by XRF. Elements are reported as wt.\% of their major oxides, for simplicity.

\begin{tabular}{lll}
\hline FA-RAW [wt.\%] & & \\
\hline & Average & SD \\
\hline $\mathrm{Al}_{2} \mathrm{O}_{3}$ & 3.65 & 0.28 \\
$\mathrm{CaO}$ & 19.9 & 0.82 \\
$\mathrm{Fe}_{2} \mathrm{O}_{3}$ & 0.79 & 0.04 \\
$\mathrm{~K}_{2} \mathrm{O}$ & 3.76 & 0.34 \\
$\mathrm{MgO}$ & 1.70 & 0.11 \\
$\mathrm{MnO}$ & 0.05 & 0.00 \\
$\mathrm{Na}_{2} \mathrm{O}$ & 5.09 & 0.64 \\
$\mathrm{P}_{2} \mathrm{O}_{5}$ & 1.25 & 0.06 \\
$\mathrm{SiO}_{2}$ & 9.48 & 1.23 \\
$\mathrm{TiO}_{2}$ & 0.95 & 0.01 \\
$\mathrm{CuO}_{\mathrm{ZnO}}$ & 0.07 & 0.00 \\
$\mathrm{PbO}$ & 1.14 & 0.04 \\
$\mathrm{Cr}_{2} \mathrm{O}_{3}$ & 0.35 & 0.03 \\
$\mathrm{Sb}_{2} \mathrm{O}_{3}$ & 0.13 & 0.01 \\
$\mathrm{Cl}$ & 0.10 & 0.00 \\
$\mathrm{SO}_{3}$ & 12.8 & 1.39 \\
$\mathrm{LOI}$ & 23.6 & 0.85 \\
\hline
\end{tabular}

\subsection{Chemical leaching}

The leaching behaviour of MSWI fly ash was investigated as a function of $\mathrm{pH}$ (e.g., Astrup et al., 2006) by testing the sample material subjected to several stages of $\mathrm{pH}$ and by analysing leach ing solutions at specific pH intervals. At the end of the experiment (i.e., at $1 \mathrm{pH}$ ), the XRF analysis of solid by product allowed assessing metal removal rates (as $\mathrm{R} \%$, Table 2), which are calculated for each element according to the Eq. (2) and the mass balance of the experiment. Chemical leaching effectively removes elements such as $\mathrm{Al}, \mathrm{Cu}, \mathrm{Fe}, \mathrm{Mg}, \mathrm{Ni}, \mathrm{P}$, and $\mathrm{Zn}$, showing $>90 \%$ yields. The leaching efficiency coupled with the relatively high concentrations of these elements within initial MSWI fly ash show significant recovery potential. Other elements such as $\mathrm{Cl}$, Mo, Na, are almost totally recovered by $\mathrm{H}_{2} \mathrm{SO}_{4}$. Among critical elements, $\mathrm{Cr}$, Sb and $\mathrm{Nd}$ show a better leaching yield (nearly 70\%) than $\mathrm{Ga}(58 \%)$, Ce (49\%), Nb (46\%), Sm (31\%), and Co (28\%). The calculated yield for lanthanides is merely qualitative owing to their high values of SD. It was also found that $40 \% \mathrm{Ca}, 50 \% \mathrm{Si}$, and $45 \% \mathrm{~Pb}$ were mobi lised. Despite $\mathrm{Ca}$ can be present as easily soluble compounds in acidic environments, the overall $\mathrm{Ca}$ release was lower with respect to similar works reported in the literature (Huang et al., 2007; Zhang and Itoh, 2006; Nagib and Inoue, 2000).

The concentration of selected elements in leachates indicates that $\mathrm{H}_{2} \mathrm{SO}_{4}$ leaching performances change as a function of $\mathrm{pH}$ (Fig. 3). Elements such as $\mathrm{Ca}$ and $\mathrm{Al}$ show a good solubility even

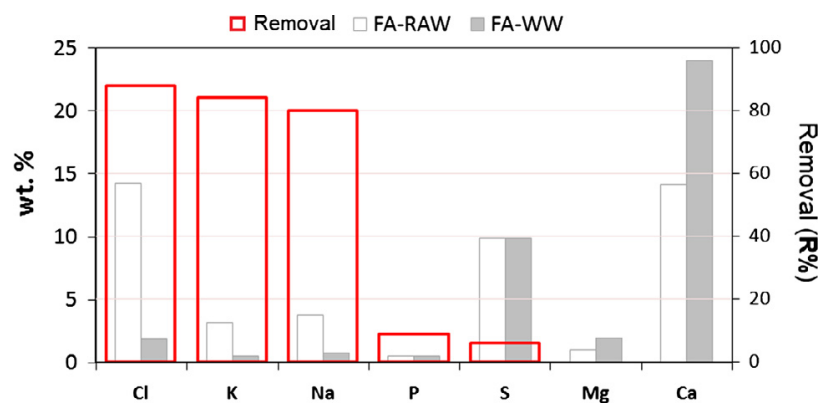

Fig. 2. Removal rates (R\%) after water washing. Yields are calculated from the chemical composition (wt.\%) of FA-RAW and FA-WW, by XRF. The most soluble elements, according to the $\mathrm{R} \%$, are shown. 
Table 2

Chemical composition of the FA-WW and samples after treatments (FA- $\mathrm{H}_{2} \mathrm{SO}_{4}$ and FA-BIO), by XRF. Calculated yield (R\%) for FA- $\mathrm{H}_{2} \mathrm{SO}{ }_{4}$ and $\mathrm{FA}-\mathrm{BIO}$ is renorted.

\begin{tabular}{|c|c|c|c|c|c|c|c|c|c|c|}
\hline & \multicolumn{2}{|c|}{ FA-WW [mg/kg] } & \multicolumn{2}{|c|}{$\mathrm{FA}-\mathrm{H}_{2} \mathrm{SO}_{4}[\mathrm{mg} / \mathrm{kg}]$} & \multicolumn{2}{|l|}{$\mathrm{R}[\%]$} & \multicolumn{2}{|c|}{ FA-BIO [mg/kg] } & \multicolumn{2}{|c|}{$\mathrm{R}[\%]$} \\
\hline & ave. & SD & ave. & SD & ave. & SD & ave. & SD & ave. & SD \\
\hline $\mathrm{Al}$ & 32,355 & 530 & 2923 & 480 & 92 & 2 & 4768 & 1659 & 86 & 7 \\
\hline As & 41 & 8 & 41 & 1 & 13 & 22 & 35 & 5 & 18 & 7 \\
\hline $\mathrm{Ba}$ & 1084 & 11 & 1115 & 29 & 10 & 2 & 920 & 50 & 19 & 5 \\
\hline $\mathrm{Ca}$ & 240,197 & 2192 & 166,301 & 1757 & 40 & 0.1 & 139,941 & 1757 & 45 & 2 \\
\hline $\mathrm{Ce}$ & 31 & 6 & 18 & 3 & 49 & 1 & 17 & 1 & 48 & 8 \\
\hline $\mathrm{Cl}$ & 18,509 & 618 & 133 & 25 & 99 & 1 & 319 & 12 & 98 & 0.4 \\
\hline Co & 12 & 1 & 10 & 1 & 28 & 0.3 & 6 & 2 & 55 & 17 \\
\hline $\mathrm{Cr}$ & 1459 & 62 & 620 & 10 & 70 & 1 & 721 & 50 & 63 & 6 \\
\hline Cs & 19 & 7 & 4 & 4 & 80 & 23 & 4 & 2.7 & 84 & 11 \\
\hline $\mathrm{Cu}$ & 881 & 20 & 51 & 4 & 95 & 0.5 & 239 & 87 & 74 & 12 \\
\hline $\mathrm{Fe}$ & 11,296 & 107 & 1149 & 214 & 91 & 2 & 5475 & 1283 & 54 & 15 \\
\hline Ga & 40 & 1 & 19 & 1 & 58 & 0.4 & 18 & 3 & 57 & 8 \\
\hline K & 5315 & 742 & 3262 & 293 & 46 & 4 & 1524 & 155 & 73 & 1 \\
\hline La & 14 & 4 & 16 & 2 & $<1$ & 24 & 10 & 2 & 30 & 11 \\
\hline $\mathrm{Mg}$ & 19,373 & 1005 & 84 & 160 & 100 & 1 & 201 & 133 & 99 & 1 \\
\hline $\mathrm{Mn}$ & 692 & 45 & 69 & 1 & 91 & 1 & 102 & 89 & 87 & 16 \\
\hline Mo & 24 & 1 & 2 & 1 & 92 & 3 & 12 & 0.3 & 50 & 0.2 \\
\hline $\mathrm{Na}$ & 8058 & 113 & 1683 & 43 & 82 & 0.3 & 1111 & 771 & 87 & 13 \\
\hline $\mathrm{Nb}$ & 17 & 0.5 & 11 & 0.6 & 46 & 2 & 13 & 0.4 & 30 & 0.3 \\
\hline $\mathrm{Nd}$ & 17 & 7 & 7 & 1 & 64 & 17 & 4 & 2 & 76 & 2 \\
\hline $\mathrm{Ni}$ & 88 & 2 & 8 & 2 & 93 & 7 & 31 & 7 & 66 & 11 \\
\hline $\mathrm{P}$ & 5301 & 206 & 182 & 25 & 97 & 0.4 & 1284 & 297 & 77 & 6 \\
\hline $\mathrm{Pb}$ & 5076 & 376 & 3792 & 120 & 45 & 3 & 2963 & 211 & 59 & 1 \\
\hline $\mathrm{Sb}$ & 1232 & 40 & 496 & 13 & 65 & 1 & 856 & 17 & 52 & 0.4 \\
\hline $\mathrm{Si}$ & 53,399 & 8282 & 30,540 & 6441 & 50 & 4 & 34,886 & 12,241 & 40 & 18 \\
\hline $\mathrm{Sm}$ & 3 & 0.3 & 2 & 0.2 & 31 & 4 & 2 & 0.1 & 9 & 9 \\
\hline $\mathrm{Sr}$ & 556 & 13 & 414 & 5 & 35 & 1 & 319 & 8 & 45 & 0.1 \\
\hline $\mathrm{Ti}$ & 10,474 & 207 & 3007 & 159 & 75 & 1 & 5543 & 330 & 50 & 3 \\
\hline V & 102 & 3 & 35 & 2 & 70 & 1 & 52 & 6 & 52 & 6 \\
\hline $\mathrm{Zn}$ & 14,400 & 433 & 1449 & 56 & 93 & 1 & 2069 & 47 & 91 & 0.2 \\
\hline $\mathrm{Zr}$ & 180 & 3 & 106 & 4 & 49 & 2 & 120 & 4 & 36 & 2 \\
\hline
\end{tabular}

Average and standard deviation (SD) values of triplicate samples are reported. The SD of R (\%) was estimated on the basis of maximum and minimum removal for each element.
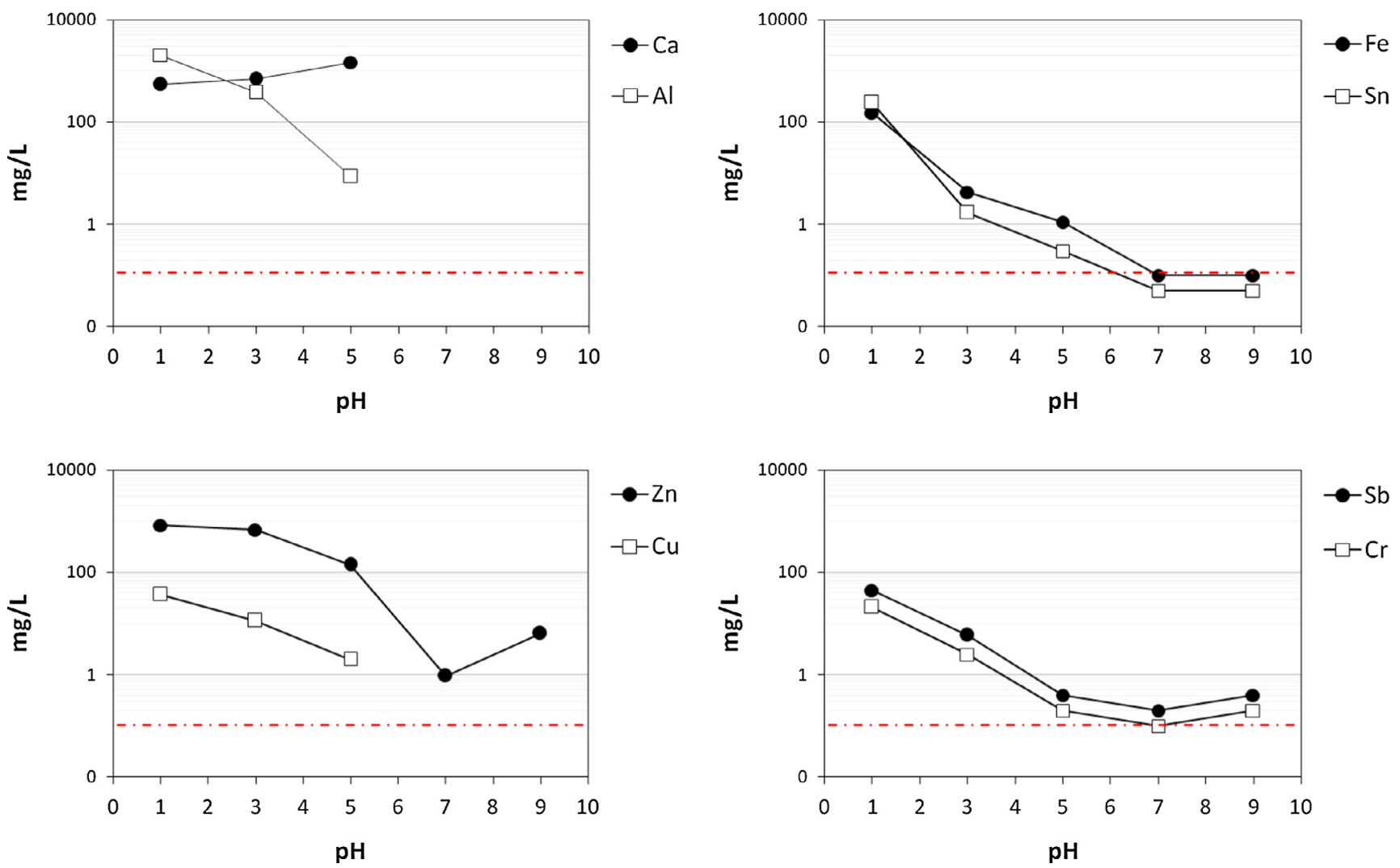

Fig. 3. Measured concentrations by ICP-AES of selected elements in leachates from $\mathrm{H}_{2} \mathrm{SO}_{4}$ leaching as a function of pH. Red dashed line is the detection limit. (For interpretation of the references to colour in this figure legend, the reader is referred to the web version of this article.) 
at $\mathrm{pH}$ intervals close to neutrality, whereas $\mathrm{Zn}, \mathrm{Cr}$, and $\mathrm{Sb}$ demon strate a slight amphoteric behaviour where removal rates fall at 7 $\mathrm{pH}$ and start rising again in alkaline conditions. Overall, removal rates and potential recovery of marketable elements (especially $\mathrm{Al}$, $\mathrm{Cu}$, and $\mathrm{Zn}$ ) from MSWI fly ash after $\mathrm{H}_{2} \mathrm{SO}_{4}$ leaching are consistent with the outcomes of previous work (Astrup et al., 2006; Zhang and Itoh, 2006; Nagib and Inoue, 2000).

\subsection{Bioleaching}

Unlike the chemical leaching procedure, the sampling from bioleaching reactor was performed over time at an initial $\mathrm{pH}$ of 1.8 , maintained with $\mathrm{H}_{2} \mathrm{SO}_{4}$ addition. The buffer capacity of the MSWI fly ash sample was greater than biologically produced sulphuric acid and this made necessary a few manual addition of sulphuric acid during the experiment (see Section 3.5.2). Acid consumption significantly decreased after three days and a steady acid consumption was achieved (Fig. 4). The sampling started on the third day and carried out each day for ten days, then three days before the end of the experiment, and at the end of the experiment (after three weeks in total). At the end of the experiment, $\mathrm{pH}$ had decreased to 1.4 , clearly below the $\mathrm{pH} 1.8$ set point, showing the activity of sulphur oxidizing bacteria and production of sulphuric acid from elemental sulphur.

The investigated elements show a high leachability already during the first days of the experiment (Fig. 5), and from the third day onwards the bioleaching reactor was close to equilibrium. The bioleaching system does not show a clear time dependence and the majority of leaching most likely occurs within 03 day. From day 3 sample to day 21 sample, data disclose a slight increase of $\mathrm{Fe}, \mathrm{Cr}$, and $\mathrm{Zn}$ concentrations in leachates and a slight decrease of $\mathrm{Cu}$ and $\mathrm{Sb}$.

The recovery performances of the bioleaching procedure, based on the XRF analysis of FA BIO solid sample, can be evaluated in Table 2. Critical and marketable elements such as $\mathrm{Mg}, \mathrm{Zn}, \mathrm{Mn}, \mathrm{Al}$, $\mathrm{Nd}$, and $\mathrm{Cu}$ show removal percentages of 99, 91, 87, 86, 76, and 74, respectively. Moreover, toxic elements such as $\mathrm{Ni}$ and $\mathrm{Pb}$, and the critical elements $\mathrm{Cr}$, $\mathrm{Co}$, and $\mathrm{Ga}$ were efficiently solubilised with removal close to $60 \%$. Other critical elements were moderately leached out from the solids, for example $52 \% \mathrm{Sb}, 48 \% \mathrm{Ce}$ and $30 \% \mathrm{Nb}$ were removed. The mobility of the unvalued $\mathrm{Si}, \mathrm{Ca}, \mathrm{Ti}$ and the harmful As from solid to solution after bioleaching is rel atively low.

\subsection{Comparison of chemical leaching vs. bioleaching}

\subsubsection{Speciation of elements within solid residues of MSWI fly ash after chemical leaching and bioleaching}

A comparison of the performance (yields) between chemical leaching and bioleaching is shown in Fig. 6 . The error bars indicate the uncertainty associated with XRF measurements for each element. A larger standard deviation is frequently associated with

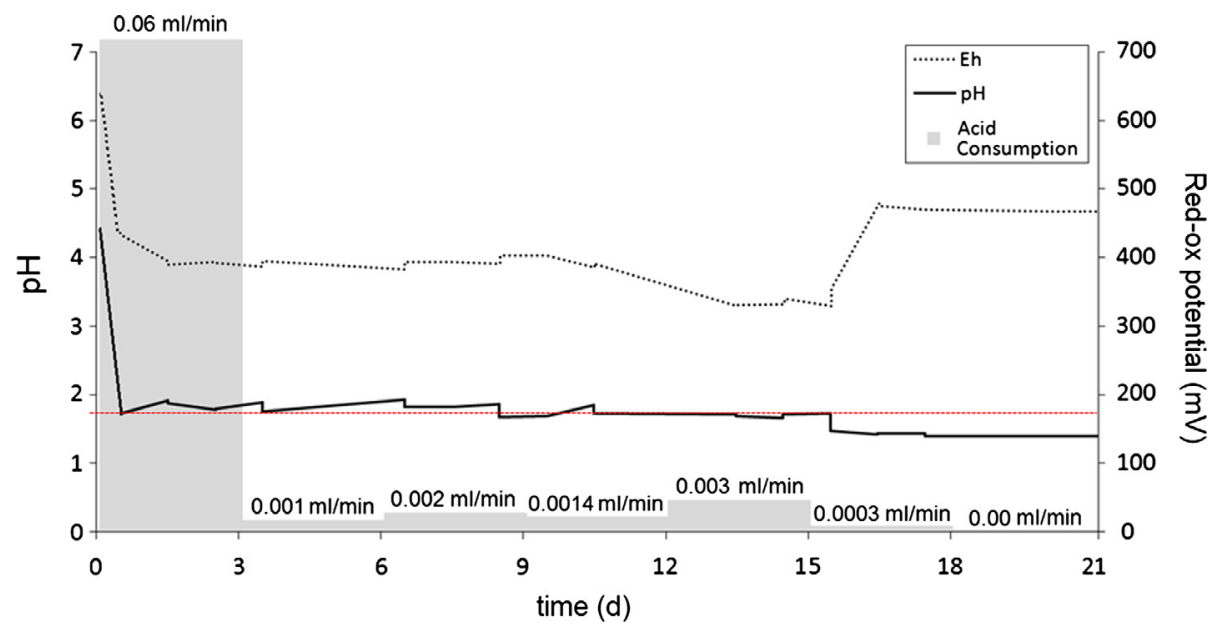

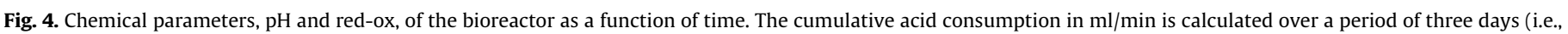

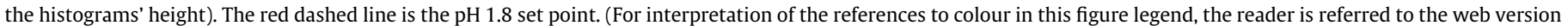
of this article.)
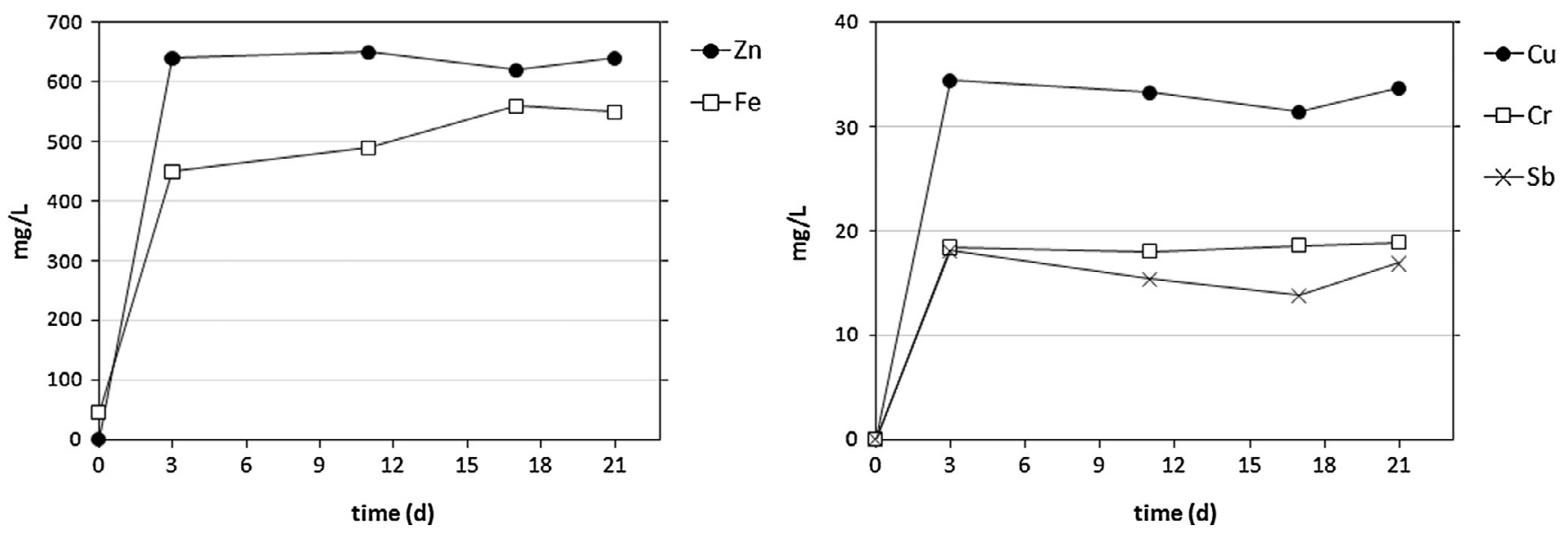

Fig. 5. Measured concentrations by ICP-AES of selected elements in leachates from bioleaching as a function of time. 

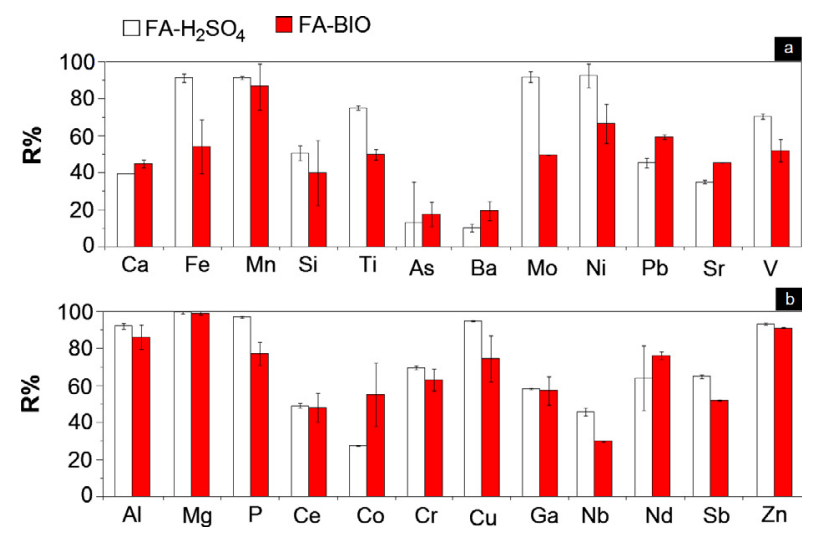

Fig. 6. Comparison of leaching yields ( $R \%$ ) between chemical leaching and bioleaching for selected unvalued/hazardous (a) and critical/marketable (b) elements. Error bars are the standard deviation of R\%.

the bioleached rather than chemically leached residue. The reasons for this discrepancy are unclear. On the basis of morphological analysis of FA RAW, FA $\mathrm{H}_{2} \mathrm{SO}_{4}$ and FA BIO (see Supplementary materials) we suggest that the formation of coarse mineral grains may promote the nugget effect.

Chemical leaching and bioleaching showed comparable yields for easily soluble elements such as $\mathrm{Al}, \mathrm{Cl}, \mathrm{Cs}, \mathrm{Mg}$, and $\mathrm{Na}$, but larger differences in $\mathrm{Ba}, \mathrm{K}, \mathrm{Mo}, \mathrm{Co}$, and Fe. The element Sm showed unreliable differences in leaching yield due to the analytical sensitivity, therefore $\mathrm{Sm}$ is not reported. Both procedures are efficient in the removal of critical/marketable metals such as $\mathrm{Al}, \mathrm{Ce}, \mathrm{Cr}, \mathrm{Ga}, \mathrm{Mg}$, and $\mathrm{Zn}$ (Fig. 6b), while a low mobilisation of Ca was noted. The presence of Ca could potentially inhibit the extraction of other elements (Kalmykova and Fedje, 2013), thus low Ca yields might be of beneficial for the quality of the final product and the overall recovery potential. The reason of low Ca release after both treatments may relate to the untreated fly ash used in the present study, which had not lime addition (typically employed in the subsequent steps of filtration to remove $\mathrm{SO}_{2}$ gas). In fact, Ca bearing com pounds within untreated fly ashes can occur in form of low soluble amorphous silicates, oxides or sulphides rather than gypsum and calcium carbonate minerals, which are instead more mobile (Zhang and Itoh, 2006).

Both procedures can be beneficial to the decontamination of MSWI fly ashes: the bioleaching enhanced the removal of several hazardous elements (Fig. 6a) such as $\mathrm{As}, \mathrm{Ba}, \mathrm{Pb}$, and $\mathrm{Sr}$ while chemical leaching is an option for the removal of Mo, Ni, and V. Overall, As was slightly mobilised from the solid material probably due to its low concentration in the FA RAW or bonding with refractory silicates.

The chemical leaching resulted in higher leaching yields for $\mathrm{Cu}, \mathrm{Fe}$, $\mathrm{Ni}, \mathrm{P}$, and $\mathrm{Sb}$ with respect to bioleaching, but the removal of unvalued elements such as $\mathrm{Si}$ and $\mathrm{Ti}$ is even high (Fig. 6a). The removal rates of $\mathrm{Co}, \mathrm{Pb}$ and $\mathrm{Nd}$ are enhanced by means of bioleach ing. Although a similar acidic environment was reached at the end of both experiments (i.e., $\mathrm{pH} 1$ for chemical leaching and $\mathrm{pH} 1.4$ for bioleaching), a different mobilisation of metals was noted and this could be related to a different reaction time (a few hours for the chemical leaching; several days for the bioleaching), but also to mechanisms of direct enzymatic reduction or other indirect activities of microorganisms (Brombacher et al., 1998). The unbalanced yields especially for $\mathrm{Co}, \mathrm{Pb}$, and $\mathrm{Nd}$ suggest that the bio produced sulphuric acid is not the sole agent of metals mobilisation. Several mechanisms might compete during leaching which, in turn, might selectively enhance or inhibit the solubilisation of some metals. The improved solubilisation of $\mathrm{Co}$ and $\mathrm{Pb}$, which partly occur in sulphide minerals within MSWI ashes, might be enhanced by
$\mathrm{Fe}^{3+}$ produced by iron oxidizing bacteria (Sand et al., 2001). These bacteria (At. ferrooxidans and L. ferrooxidans) were found from the mixed acidophilic culture and were most likely oxidizing acid dissolved $\mathrm{Fe}^{2+}$ to $\mathrm{Fe}^{3+}$ during bioleaching:

$2 \mathrm{Fe}^{2+}+0.5 \mathrm{O}_{2}+2 \mathrm{H}^{+} \rightarrow 2 \mathrm{Fe}^{3+}+\mathrm{H}_{2} \mathrm{O}$

On the other hand, lanthanides can accumulate on cell wall or bacteriogenic oxides (Moriwaki and Yamamoto, 2013). The effect of red ox reactions induced by bacteria, such as biotic oxidation of $\mathrm{Fe}^{2}$

+ to $\mathrm{Fe}^{3+}$ that catalyses metals solubilisation, might play an important role on leaching efficiency and will be the object of a forthcoming paper.

\subsubsection{Effect of $\mathrm{pH}$ and acid consumption/production}

The overall acid consumption during chemical leaching was $2.014 \mathrm{l}$ of concentrated (96\% purity) $\mathrm{H}_{2} \mathrm{SO}_{4}$ per $\mathrm{kg}$ of FA WW, while 0.8101 during bioleaching. The added value for bioleaching is the limited consumption of sulphuric acid, two times less than chemical leaching, illustrating the activity of sulphur oxidizing bacteria and their capability to produce remarkable amounts of $\mathrm{H}_{2} \mathrm{SO}_{4}$. According to the Eq. (1), biologic transformation of 1 ton of elemental sulphur produces approximately 3 tons of $\mathrm{H}_{2} \mathrm{SO}_{4}$. In U.S. (2013) the price of elemental sulphur and imported $\mathrm{H}_{2} \mathrm{SO}_{4}$ product was 69 and $63 \$ / t$, respectively (USGS, 2015). Therefore, chemical costs for bio based $\mathrm{H}_{2} \mathrm{SO}_{4}$ are three times lower than the price of imported sulphuric acid.

\subsubsection{Potential environmental implication}

According to the European regulation (European Union, 2002), the limit values for waste acceptance at landfills are based on a leaching procedure (TCPL, Toxicity Characteristic Leaching Procedure), which have to follow Technical Specification of the European Committee for Standardization. Although our experiments do not comply with the standard procedures for TCLP as it was not in the scope of the present work, Table 3 shows that the composition of treated MSWI ashes are below the European guidance levels (for leachates) for several regulated chemical elements such as $\mathrm{Cl}, \mathrm{Cu}$, $\mathrm{Mo}, \mathrm{Ni}$, and $\mathrm{V}$. Other harmful elements within solid by products largely exceed the TCPL limits and likely have an impact on the environment.

Limit values for waste acceptance in landfill or for waste reuse as construction material are not available for solids. Data of solid residues after chemical leaching and bioleaching treatments can be compared with guidance levels published by BAFU (Federal Office for the Environment, Switzerland) as suggested elsewhere for other incineration ashes (Nowak et al., 2010). The comparison helps assessing whether treated residues can be reused and, thus, can constitute an added value product rather than a secondary waste. The solid residues produced at the end of bio hydrometallurgical treatments do not meet the guidance levels of BAFU for a number of elements (Table 3). Harmful elements such as $\mathrm{Zn}, \mathrm{Cr}, \mathrm{Pb}$, and $\mathrm{Sb}$ were significantly removed, but they still keep high concentrations and prevent the residues' landfilling. The solid by products have potential for re use after further removal of these elements, especially $\mathrm{Pb}$ and $\mathrm{Sb}$.

\subsection{The management of MSWI fly ash}

The management of fly ashes represents a significant cost for the incineration plants. In particular, an evident new route in fly ash management is the recovery of secondary raw material from this type of solid residue. If successful, the recovery of valuable metals will have a twofold aim: environmental stabilisation of this hazardous waste and revenues from the recovered metals. These will certainly impact on the economics of an incineration plant. 
Table 3

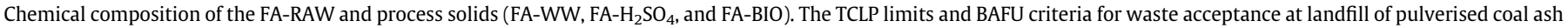
and blast furnace slag are also reported.

\begin{tabular}{|c|c|c|c|c|c|c|c|c|c|c|c|}
\hline & \multicolumn{2}{|l|}{ FA-RAW } & \multicolumn{2}{|l|}{ FA-WW } & \multicolumn{2}{|l|}{$\mathrm{FA}-\mathrm{H}_{2} \mathrm{SO}_{4}$} & \multicolumn{2}{|l|}{ FA-BIO } & \multicolumn{3}{|c|}{ Guidance levels } \\
\hline & \multicolumn{2}{|c|}{ Average RSD\% } & \multicolumn{2}{|c|}{ Average RSD\% } & \multicolumn{2}{|c|}{ Average RSD\% } & \multicolumn{2}{|c|}{ Average RSD\% } & TCPL & Coal & Slag \\
\hline \multicolumn{12}{|c|}{$(\mathrm{mg} / \mathrm{kg})$} \\
\hline $\mathrm{Ca}$ & 142,000 & 4 & 240,200 & 1 & 166,300 & 1 & 139,900 & 3 & - & - & - \\
\hline $\mathrm{Cl}$ & 142,000 & 10 & 18,500 & 3 & 130 & 17 & 300 & 3 & 25,000 & - & - \\
\hline S & 105,700 & 3 & 106,200 & 4 & 232,000 & 1 & 177,500 & 4 & 50,000 & - & - \\
\hline $\mathrm{Si}$ & 44,300 & 12 & 53,400 & 17 & 30,500 & 19 & 34,900 & 28 & - & - & - \\
\hline $\mathrm{Na}$ & 37,700 & 11 & 8000 & 2 & 1700 & 2 & 1100 & 55 & - & - & - \\
\hline $\mathrm{K}$ & 31,200 & 8 & 5300 & 15 & 3300 & 8 & 1500 & 8 & - & - & - \\
\hline $\mathrm{Al}$ & 19,300 & 7 & 32,400 & 2 & 2900 & 15 & 4800 & 27 & - & - & - \\
\hline $\mathrm{Mg}$ & 10,300 & 11 & 19,400 & 6 & 80 & 173 & 200 & 52 & - & - & - \\
\hline $\mathrm{Zn}$ & 10,200 & 3 & 14,400 & 3 & 1400 & 4 & 1600 & 2 & 250 & 1000 & 400 \\
\hline $\mathrm{Ti}$ & 5700 & 1 & 10,500 & 2 & 3000 & 5 & 5500 & 5 & - & - & - \\
\hline $\mathrm{Fe}$ & 5500 & 5 & 11,300 & 1 & 1100 & 17 & 5400 & 18 & - & - & - \\
\hline $\mathrm{P}$ & 5500 & 4 & 5300 & 4 & 180 & 12 & 1200 & 18 & - & - & - \\
\hline $\mathrm{Pb}$ & 3400 & 8 & 5100 & 7 & 3800 & 3 & 3000 & 7 & 5 & 300 & 75 \\
\hline $\mathrm{Cr}$ & 1500 & 4 & 1500 & 3 & 600 & 3 & 700 & 11 & 5 & 300 & 200 \\
\hline $\mathrm{Ba}$ & 900 & 4 & 1080 & 1 & 1100 & 3 & 900 & 5 & 100 & 1500 & 1000 \\
\hline $\mathrm{Sb}$ & 900 & 1 & 1300 & 3 & 500 & 3 & 860 & 2 & 150 & 10 & 5 \\
\hline $\mathrm{Cu}$ & 600 & 2 & 900 & 2 & 50 & 7 & 200 & 36 & 250 & 200 & 200 \\
\hline $\mathrm{Sr}$ & 500 & 4 & 560 & 2 & 400 & 1 & 300 & 3 & 1 & - & - \\
\hline Mn & 370 & 1 & 690 & 7 & 70 & 0 & 100 & 69 & - & - & - \\
\hline V & 80 & 3 & 100 & 3 & 30 & 6 & 50 & 12 & 250 & 300 & 300 \\
\hline $\mathrm{Ni}$ & 50 & 14 & 90 & 1 & 10 & 63 & 30 & 23 & 250 & 200 & 200 \\
\hline As & 30 & 13 & 40 & 19 & 40 & 2 & 30 & 13 & 5 & 40 & 30 \\
\hline Mo & 20 & 6 & 20 & 2 & 2 & 26 & 10 & 3 & 30 & - & - \\
\hline Co & 8 & 14 & 12 & 11 & 10 & 4 & 6 & 28 & - & 100 & 100 \\
\hline
\end{tabular}

However, there is no a unique solution for the treatment of MSWI fly ash. The current technologies involve physical and chemical treatments such as eddy current separators, thermal treatments, electrochemical processes, and hydrometallurgy. These routes of treatment, which often consist of step wise treatments (e.g., washing, milling, sieving, and subsequent thermal or hydrometallurgical processes), produce physical and chemical state changes to stabilise hazardous compounds and enhance the mechanical properties of the final product. One of the main advantages of these approaches is a fast reaction kinetic. Nevertheless, such process chains are costly because they require a high consumption of energy and/or chemicals, producing an adverse effect on the process economics. Despite some treatment strategies have been proposed and commercialised, the experimental results don't suffice to validate a more widespread implementation. For example, treat ment options for the production of glass ceramic, cement clinkers, geo polymers, synthetic zeolites or other adsorbents from MSWI fly ashes were found to be inefficient for the complete stabilisation of hazardous compounds and/or for the conversion of raw fly ashes into a material with good mechanical characteristics (e.g., De Casa et al., 2007); hydrometallurgical methods for metals recovery have the disadvantage of a massive use of mineral acid and still lack in well targeted techniques for the (re)precipitation of metals from the enriched solutions. Due to these technology gaps the manage ment of fly ash still represents a huge cost for MSWI companies.

A successful technology to be applied in the field of waste management relies on process sustainability and has to meet a market demand. The main economic motivation for the treatment of MSWI fly ash is $\mathrm{Zn}$ and $\mathrm{Al}$ recovery and the loss of these metals can be reduced using an integrated strategy. The separation of the non ferrous fraction for the recovery of $\mathrm{Al}$ is a quite common practice, even if is mainly applied for bottom ash, because it combines metal recovery and enhanced mechanical properties of by products in a relatively cost effective manner. However, the mechanical separation requires further steps to obtain metals of adequate quality for the re introduction into the raw material market (Biganzoli et al., 2012). Because of the lower Al contents in MSWI fly ashes with respect to bottom ashes (Funari et al., 2015), any investment in this sense is virtually uneconomic. Similar is the case of Zn. Fellner et al. (2015) indicated that the most of Zn from MSWI fly ashes is hardly extractable because the production costs would be at least 10 times higher than current $\mathrm{Zn}$ market price. Significant amount of $\mathrm{Zn}$ can be extracted at low $\mathrm{pH}$ values, requiring huge amounts of acid. This prevents a positive balance between the agent costs of a hypothetical treatment process and the economic gains.

Both leaching methods tested here sufficiently extract marketable metals including $\mathrm{Al}$ and $\mathrm{Zn}$, and the outcomes deriving from this comparison can act as a testing ground for future fine tuned experiments in view of widespread implementation of a new MSWI fly ashes value chain for the recovery of certain metals from this low grade high flow waste stream.

Future experiments should be addressed to improve stabilisation of solid by products and metal recovery from process solutions: they might include leaching at elevated temperatures, high acid composition and combined bioleaching and chemical leaching to utilise the selectivity differences and maximise recoveries and environmental status of the residue. Chlorides and alkali salts, which are substantially unvalued/hazardous compounds and may hinder the recovery of marketable metals, can be leached out by water (see Fig. 2) and the pre washing treatment might be further optimised towards improved removal amounts. Other impurities such as Fe and Mn can be removed by drop wise adding $\mathrm{NaOH}$ and $\mathrm{KMnO}_{4}$, respectively, to the leaching liquor at room temperature, as in Chen et al. (2015). Marketable elements can be recovered from process solutions by solvent extraction or ion exchange experiments (e.g., Tang and Steenari, 2015). Well known methods such as thermal treatments and carbonation (e.g., Nowak et al., 2010; De Casa et al., 2007) might lead to inert solid by products in a closed loop strategy.

\subsubsection{The route of bioleaching for potential industrial application}

Developing new and less costly methods is extremely important to provide recycling alternatives and, in this view, the bioleaching offers an opportunity for a potential industrial roll out. Although the $\mathrm{H}_{2} \mathrm{SO}_{4}$ leaching is still not affordable for industrial application 


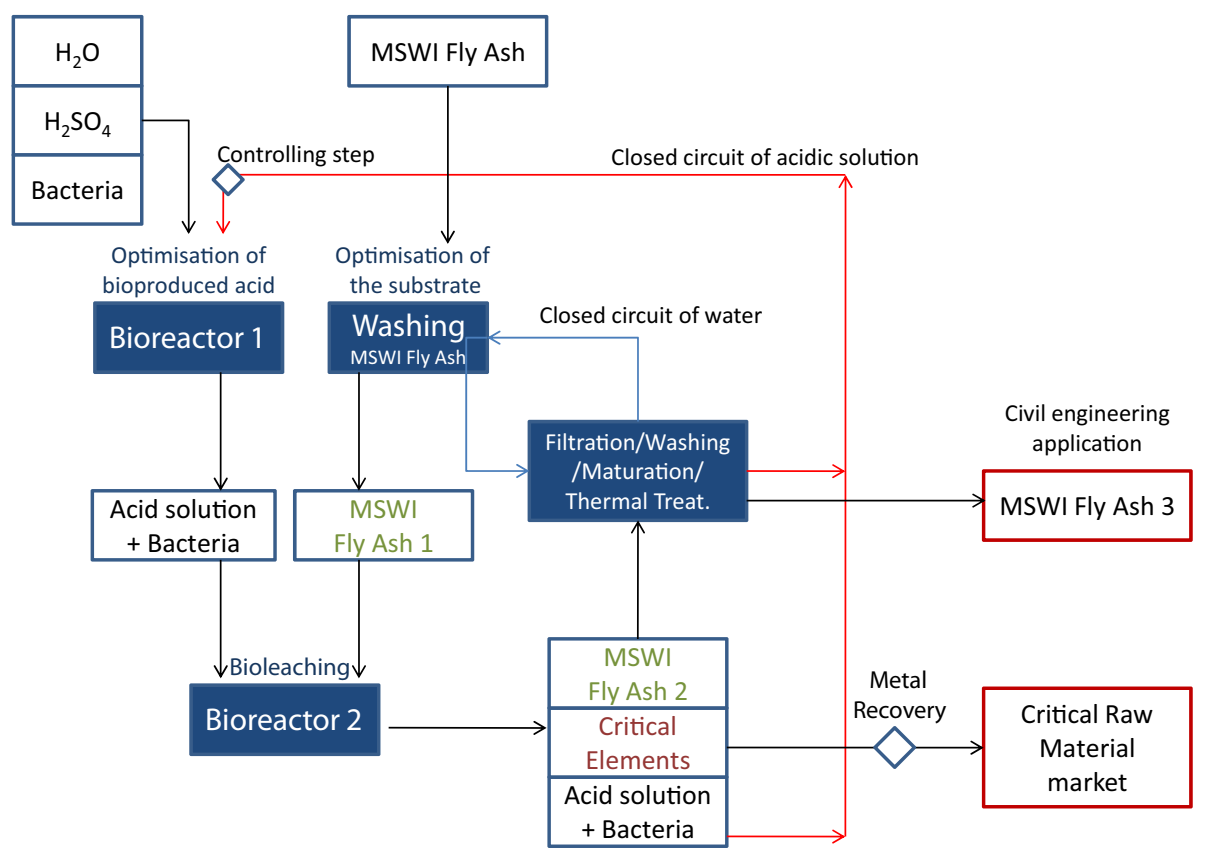

Fig. 7. Flow sheet of a hypothetical process chain for the treatment of MSWI fly ash.

(Meawad et al., 2010; Okada et al., 2007), the bioleaching in sulphuric acid solution, under our experimental conditions, resulted in satisfactory removals, low amount of unvalued elements in the leachate, and low agent costs for $\mathrm{H}_{2} \mathrm{SO}_{4}$ (due to bio produced acid) and transportation (the process can be implemented on site). As a consequence of this resource saving approach, enhancing the leaching yields with pre treatment steps will moderately impact on the process economic. The bioleaching procedure has a great (and relatively unexplored) potential for optimisation with limited additional costs, e.g., by improving medium $\left(\mathrm{S}^{0}, \mathrm{Fe}^{2+}\right.$, nutrients) and substrate quality, thermo chemical conditions, inoculum volume and fraction of bacterial strains. Chemical leaching at $\mathrm{pH} 1.0$ removes some elements (e.g., $\mathrm{Cu}, \mathrm{Fe}, \mathrm{Ni}, \mathrm{P}$, and $\mathrm{Sb}$ ) better than bioleaching at $\mathrm{pH}$ 1.4. The possible requirement for a low $\mathrm{pH}$ is not a process limiting factor in bioleaching as, for example, the well known sulphur oxidizing bacterium, At. thiooxidans, can thrive even in pH 0.5 (Bosecker, 1997). Therefore, the $\mathrm{pH}$ can be adjusted to the desired level also in bioprocess, but this tends to be relatively far away from their $\mathrm{pH}$ optimum (between $\mathrm{pH} 1.0$ and 2.5) and can have an effect on the bioprocess performance that should be tested before implementation. The production rate of the $\mathrm{H}_{2} \mathrm{SO}_{4}$ is clearly the limiting factor, as bioleaching required addi tions of sulphuric acid during the main leaching period (days 03 ). Therefore, the potential industrial application for fly ash bioleaching would consist of two reactors, the first one optimised for biologic $\mathrm{H}_{2} \mathrm{SO}_{4}$ production from elemental sulphur (in the absence of fly ash) and the second reactor utilizing this bio based lixiviant for fly ash chemical leaching. In Fig. 7 we report the con ceptual design of a hypothetical treatment strategy for MSWI fly ash. It involves two optimised bioreactors ensuring closed circuits of washing water and acidic solution, and suggests industrial uses of process by products.

\section{Conclusions}

Fly ash samples from an Italian incinerator of municipal solid waste were treated by chemical leaching and bioleaching in glass reactors after a pre washing treatment. The results can be sum marised as following:
(1) Both processes resulted in good leaching yields (>85\%) for a number of elements, especially for $\mathrm{Al}, \mathrm{Cu}, \mathrm{Mg}, \mathrm{Mn}$, and $\mathrm{Zn}$, which can be potentially recovered from solutions by known methods, and low removals for Ca ( 40\%) and As ( 10\%).

(2) Chemical leaching still demonstrated higher yields than bioleaching for elements such as $\mathrm{Al}, \mathrm{Mg}, \mathrm{Zn}, \mathrm{Cu}, \mathrm{Ni}, \mathrm{Sb}$, and $\mathrm{Sn}$.

(3) Bioleaching showed good yields also for $\mathrm{Pb}, \mathrm{Ce}, \mathrm{Co}, \mathrm{La}, \mathrm{Nd}$ and $\mathrm{Sb}$ with the advantage of significant selectivity (especially for toxic elements) and lower removal of un necessary elements (e.g., Si and Ti) compared to chemical leaching. In addition, the bio produced $\mathrm{H}_{2} \mathrm{SO}_{4}$ favourably impacts on agent costs for reagents.

(4) Final residues deriving from the two methods under the experimental conditions used in this work (leaching time, temperature, and acid composition) cannot be reused as construction material and need further processing for land filling as non hazardous or inert waste status. A process chain for MSWI fly ash treatment, which includes optimised bioreactors and suggests the final destination of by products, could be tested for industrial application.

\section{Acknowledgements}

Valuable suggestions from Päivi Kinnunen, Roberta Bertani, Jakob Lederer, Alessandra Polettini and Oumaya Yazoghli Marzouk helped to improve the manuscript. Suvi Aalto, Pekka Kronqvist and Giorgio Gasparotto are warmly thanked for their technical support. Three anonymous reviewers and the Associate Editor are thanked for the comments that helped us to write a bet ter manuscript. R.B. acknowledges the SPINNER consortium (http://www.spinner.it) and Giovanni Gabbianelli (University of Bologna) for funding the scholarship to V.F. The financial support of VTT Technical Research Centre of Finland, the MarcoPolo pro gramme funds to V.F. and RFO Unibo to R.B are also acknowledged.

\section{Appendix A. Supplementary material}

Supplementary data associated with this article can be found, in the online version, at http://dx.doi.org/10.1016/j.wasman.2016.07. 025. 


\section{References}

Astrup, T., Dijkstra, J.J., Comans, R.N.J., Van der Sloot, H.A., Christensen, T.H., 2006 Geochemical modeling of leaching from MSWI air-pollution-control residues. Environ. Sci. Technol. 40 (11), 3551-3557.

Bayuseno, A.P., Schmahl, W.W., 2011. Characterization of MSWI fly ash through mineralogy and water extraction. Resour. Conserv. Recy. 55 (5), 524-534.

Biganzoli, L., Gorla, L., Nessi, S., Grosso, M., 2012. Volatilisation and oxidation of aluminium scraps fed into incineration furnaces. Waste Manage. 32 (12), 2266-

2272.

Bosecker, K., 1997. Bioleaching: metal solubilization by microorganisms. FEMS Microbiol. Rev. 20, 591-604.

Brombacher, C., Bachofen, R., Brandl, H., 1998. Development of a laboratory-scale leaching plant for metal extraction from fly ash by Thiobacillus strains. Appl.

Environ. Microbiol. 64 (4), 1237-1241.

Chen, X., Xu, B., Zhou, T., Liu, D., Hu, H., Fan, S., 2015. Separation and recovery of metal values from leaching liquor of mixed-type of spent lithium-ion batteries. Sep. Purif. Technol. 144, 197-205.

De Casa, G., Mangialardi, T., Paolini, A.E., Piga, L., 2007. Physical-mechanical and environmental properties of sintered municipal incinerator fly ash. Waste

Manage. 27 (2), 238-247.

European Commission, 2014. Report on Critical Raw Materials for EU. Report of the Ad hoc Working Group on defining critical raw materials.

European Union, 2002. Council Decision of 19 December 2002: Establishing Criteria and Procedures for Acceptance of Waste at Landfills Pursuant to Article 16 and

Annex II to Directive 1999/31/EC. European Union, Brussels.

Fellner, J., Lederer, J., Purgar, A., Winterstetter, A., Rechberger, H., Winter, F., Laner, D., 2015. Evaluation of resource recovery from waste incineration residues-the case of zinc. Waste Manage. 37, 95-103.

Funari, V., Braga, R., Bokhari, S.N., Dinelli, E., Meisel, T., 2015. Solid residues from Italian municipal solid waste incinerators: a source for "critical" raw materials.

Waste Manage. 45, 206-216.

Funari, V., Bokhari, S.N., Vigliotti, L., Meisel, T., Braga, R., 2016a. The rare earth elements in municipal solid waste incinerators ash and promising tools for their prospecting. J. Hazard. Mater. 301, 471-479.

Funari, V., Meisel, T., Braga, R., 2016b. The potential impact of municipal solid waste incinerators ashes on the anthropogenic osmium budget. Sci. Total Environ.

541, 1549-1555.

Halinen, A.-K., Rahunen, N., Kaksonen, A.H., Puhakka, J.A., 2009. Heap bioleaching of a complex sulfide ore: Part I. Effect of $\mathrm{pH}$ on metal extraction and microbial composition in $\mathrm{pH}$ controlled columns. Hydrometallurgy 98 (1-2), 92-100.

Hasegawa, H., Rahman, I.M.M., Egawa, Y., Sawai, H., Begum, Z.A., Maki, T., Mizutani, S., 2014. Recovery of the rare metals from various waste ashes with the aid of temperature and ultrasound irradiation using Chelants. Water Air Soil Pollut. 225 (9), 2112.

Hong, K.J., Tokunaga, S., Kajiuchi, T., 2010. Extraction of heavy metals from MSW incinerator fly ashes by chelating agents. J. Hazard. Mater. 75, 57-73.

Huang, S.-J., Chang, C.-Y., Mui, D.T., Chang, F.-C., Lee, M.-Y., Wang, C.-F., 2007. Sequential extraction for evaluating the leaching behavior of selected elements in municipal solid waste incineration fly ash. J. Hazard. Mater. 149 (1), 180-188.
Ishigaki, T., Nakanishi, A., Tateda, M., Ike, M., Fujita, M., 2005. Bioleaching of meta from municipal waste incineration fly ash using a mixed culture of sulfur-oxidizing and iron-oxidizing bacteria. Chemosphere 60 (8), 1087-1094. Kalmykova, Y., Fedje, K.K., 2013. Phosphorus recovery from municipal solid waste incineration fly ash. Waste Manage. 33 (6), 1403-1410.

Lee, J.C., Pandey, B.D., 2012. Bio-processing of solid wastes and secondary resources for metal extraction - a review. Waste Manage. 32 (1), 3-18.

Meawad, A.S., Bojinova, D.Y., Pelovski, Y.G., 2010. An overview of metals recovery from thermal power plant solid wastes. Waste Manage. 30 (12), 2548-2559. Morf, L.S., Gloor, R., Haag, O., Haupt, M., Skutan, S., Di Lorenzo, F., Boni, D., 2013. Precious metals and rare earth elements in municipal solid waste-sources and

fate in a Swiss incineration plant. Waste Manage. 33 (3), 634-644. Moriwaki, H.,

Yamamoto, H., 2013. Interactions of microorganisms with rare earth ions and their utilization for separation and environmental technology. Appl. Microbiol. Biotechnol. 97 (1), 1-8.

Müller, U., Rübner, K., 2006. The microstructure of concrete made with municipal waste incinerator bottom ash as an aggregate component. Cem. Concr. Res. 36 (8), 1434-1443.

Nagib, S., Inoue, K., 2000. Recovery of lead and zinc from fly ash generated from municipal incineration plants by means of acid and/or alkaline leaching. Hydrometallurgy 56, 269-292.

Nowak, B., Pessl, A., Aschenbrenner, P., Szentannai, P., Mattenberger, H., Rechberger, H., Hermann, L., Winter, F., 2010. Heavy metal removal from municipal solid waste fly ash by chlorination and thermal treatment. J. Hazard. Mater. 179 (1-3), 323-331.

Okada, T., Tojo, Y., Tanaka, N., Matsuto, T., 2007. Recovery of zinc and lead from fly ash from ash-melting and gasification-melting processes of MSW-comparison and applicability of chemical leaching methods. Waste Manage. 27 (1),69-80. Rawlings, 65-91.

Sabbas, T., Polettini, A., Pomi, R., Astrup, T., Hjelmar, O., Mostbauer, P., Cappai, G., Magel, G., Salhofer, S., Heuss-Assbichler, S., Klein, R., Lechner, P., 2003. Management of municipal solid waste incineration residues. Waste Manage. 23 (1), 61-88.

Sand, W., Gehrke, T., Jozsa, P.-G., Schippers, A., 2001. (Bio)chemistry of bacterial leaching-direct vs. indirect bioleaching. Hydrometallurgy 59, 159-175. Silverman, M.P., Lundgren, D.G., 1959. Studies on the chemoautotrophic iron bacterium Ferrobacillus Ferrooxidans: I. An improved medium and a harvesting procedure for securing high cell yields. J. Bacteriol. 77 (5), 642-647.

Tang, J., Steenari, B.M., 2015. Solvent extraction separation of copper and zinc from MSWI fly ash leachates. Waste Manage. 44, 147-154.

USGS, 2015. 2013 Minerals Yearbook, Sulfur (Advance release). <http://minerals usgs.gov/minerals/pubs/commodity/sulfur/myb1-2013-sulfu.pdf>.

Wang, Q., Yang, J., Wang, Q., Wu, T., 2009. Effects of water-washing pretreatment on bioleaching of heavy metals from municipal solid waste incinerator fly ash. J.

Hazard. Mater. 162 (2-3), 812-818.

Zhang, F.S., Itoh, H., 2006. Extraction of metals from municipal solid waste incinerator fly ash by hydrothermal process. J. Hazard. Mater. 136 (3), 663-670. 